\title{
Our Living Earth
}

Earth is a beautiful place to live and these titles help us think about taking care of it. In addition to teaching us ways to look after the planet, many of these titles present a balanced view of equality across animate and inanimate beings with the survival of all treated as important as the survival of one.

Inspiring eco practices and teaching about the land and its sustainable resources are goals of many contemporary picture books, and Canadian writers and artists are leading the way. We admire the feelings of respect that their words and illustrations inspire in relation to all things great and small in our shared world. In reading these books, a variety of audiences will see ways that they can make a difference to their environment, now and in the future.

This chapter presents spectacular books dedicated to our living Earth, selected from an increasing number of books on this theme. One of the aspects of these books that is particularly noteworthy is their amazing illustrations - created with a wide range of media that delights the eye. In recent years, growth in non-fiction titles has skyrocketed, perhaps to compensate for past favouritism shown to fiction, and all aspects of their production - language, visual appeal, accuracy - have received excellent attention from publishers. It's possible that children's publishing is also responding to new school curricula, especially the emphasis on Science, Technology, Engineering and Mathematics (STEM) education.

In addition to the titles in this chapter, we mention other non-fiction picture books in Chapter 10 (Facts and Figures) as well as through connections to the themes of our other chapters. Where not otherwise indicated, the name of the author(s) appears first under each title, and the illustrator last.

\section{The Imperfect Garden}

Melissa Assaly

and April Dela Noche Milne

A child notices that the fruits and vegetables in their home garden look different from symmetrical store-bought produce. This title emphasises the fact that although home-grown food may look different, it really tastes great. For ages $5^{-8}$.

(C) BEVERLEY BRENNA, RICHARD DIONNE AND THERESA TAVARES, 2021 


\section{Flow Spin Grow: Looking for Patterns in Nature}

Patchen Barss

and Todd Stewart

This title explores various repeated patterns found in nature and the reasons for these patterns. The illustrations were created with silkscreen printing and digital media. An author's note at the end of the book encourages readers to pay close attention to what we see around us, in order to discover how the world works. For ages $7-9+$.

\section{Where Are You Now?}

Tyler Clark Burke

This is a book about transformation: a star turns into dust; a snowflake into water, then fog and mist... told in simple, free-verse stanzas, it connects to the way we look towards new life to remember people we have lost. The pencil and watercolour illustrations are subtle, vividly illuminating ideas inspired by the text. For ages 4-10+.

\section{Forest: A See to Learn Book}

Kate Moss Gamblin

and Karen Patkau

This gently questioning picture book prompts children to look and see into the forest across the seasons. Very young listeners will enjoy finding plants and animals in Karen Patkau's dynamic, digitally composed illustrations. A page at the end suggests further reading, a common element in many of the books in this section. For ages $2-7$.

\section{Earthrise: Apollo 8 and the Photo that Changed the World James Gladstone \\ and Christy Lundy}

This title ponders the sight of the whole planet - no countries, no borders captured in a photo from the Apollo 8 mission. Text includes dialogue pulled from NASA's Apollo 8 transcript, and an author's note explains more about how "Earthrise" went on to inspire Earth Day. Rather than photographs, the illustrator has used understated line drawings in gentle colours that represent the era depicted. For ages $4-8$. 


\section{Turtle Pond}

James Gladstone

and Karen Reczuch

A boy and his family visit the local public gardens throughout the year to see the turtles. In lyrical free verse, readers learn the habits of Red-eared Sliders across the seasons, with an extra page of information included at the end of the book. Karen Reczuch's illustrations, made with graphite pencil and watercolour, are particularly engaging in this celebration of turtles. For ages 4-8.

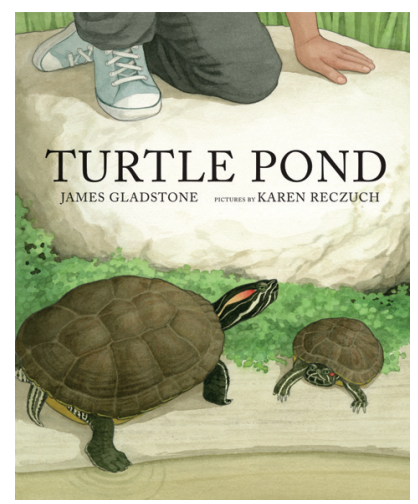

When Planet Earth Was New

James Gladstone

and Katherine Diemert

With simple, large font and brilliant, digitally augmented watercolour illustrations, this book takes us through the history of our Earth. It begins billions of years ago, and ends with the present time. A two-page spread near the end of the book offers a more complex narrative on the transformations in climate, geology, and biology, among other things, followed by a glossary and references to additional sources. For ages 6-9.

\section{When Wolves Howl}

Georgia Graham

This narrative picture book, set in the Rocky Mountains of Alberta, presents life in a wolf pack through the story of Haze, the Omega wolf, the least powerful of the group, as he comes into his own and grows up. Georgia Graham paints with acrylic on canvas and illustrates with chalk pastels on sanded paper. For ages $5^{-8 .}$ 


\section{The Sockeye Mother}

Hetxw'ms Gyetxw (Brett David Huson)

and Natasha Donovan

The life cycle of the sockeye salmon is depicted here through text created by Hetxw'ms Gyetxw (Brett David Huson), a writer from the Gitzxan Nation in the Northwest Interior of British Columbia. Illustrations are provided by artist Natasha Donovan, from Vancouver, who is a member of the Métis Nation of вс. This book explores how the animals, water, soil, seasons, and traditional knowledge are all interconnected. For ages 8-12.

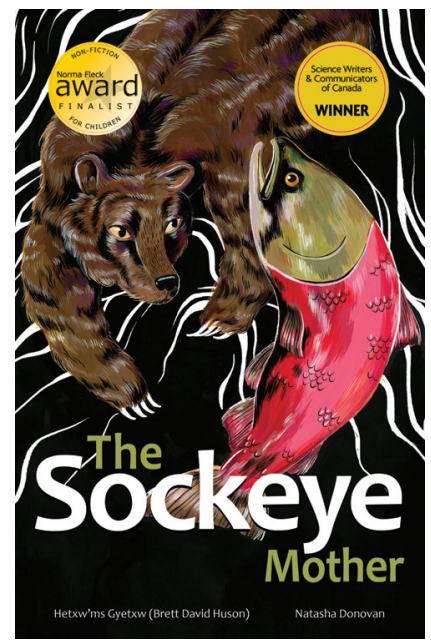

\section{The Case of the Growing Bird Feeder}

Eric Hogan \& Tara Hungerford

Scout and Daisy are having a picnic when Daisy remembers that she needs to water her bird feeders. But what kind of bird feeders need watering? Various clues are given as the book progresses towards the answer... sunflowers! Information about sunflowers "from Daisy's library book," along with a recipe for birdseed cookies, conclude this title. The 3 D illustrations are original to the book, although reminiscent of the stop motion from the СвС TV series The Gumboot Kids. For ages 3-8.

\section{The Case of the Story Rock}

Eric Hogan \& Tara Hungerford

As with the previous title, this book is connected to a TV series that champions the magic of nature. In this story, a fossil offers clues to life past and present. The stop-motion style images are unique and appealing. For ages $3-8$.

\section{The Case of the Vanishing Caterpillar}

\section{Eric Hogan \& Tara Hungerford}

As with the two previous titles, this book is connected to a TV series that uncovers mysteries in nature. The clues in this one lead from a caterpillar to its transformation into a butterfly, with stop-motion $3 \mathrm{D}$ images throughout. For ages $3-8$. 


\section{The Case of the Wooden Timekeeper}

Eric Hogan and Tara Hungerford

In a series that includes the previous three titles, this story is about how tree rings show the passage of time. Stop-motion ${ }_{3} \mathrm{D}$ images accompany the text. For ages $3-8$.

\section{Charles}

S. E. Hume

and Jessica Bromley Bartram

A young girl relates the story of raising a baby crow and then releasing him into the wild. Watermedia illustrations showcase nature in this graceful tale. For ages $3-8$.

\section{Animals Do, Too! How They Behave Just Like You}

\section{Etta Kaner}

and Marilyn Faucher

In a question and answer format, similarities are drawn between the lives of children and animals. A final two-page-spread presents more about the animals depicted in this book. Marilyn Faucher's watercolour illustrations are bright and amusing, bringing the text to life. For ages $4-8$.

\section{Do Frogs Drink Hot Chocolate? How Animals Keep Warm}

\section{Etta Kaner}

and John Martz

In typical form, Etta Kaner's question and answer format takes a humorous look at animals and includes accurate information for young readers who wonder about how various animals survive in cold weather. For ages 4-8.

\section{Once upon a Jungle}

Laura Knowles

and James Boast

This book explores a rainforest ecosystem through simple text describing a food web. A double-page spread folds out into a giant panorama towards the end of the book, and the last pages tell the story of the food chain in more detail. For ages $3^{-8 .}$ 


\section{Bowhead Whale \\ Joanasie Karpik \\ and Sho Uehara}

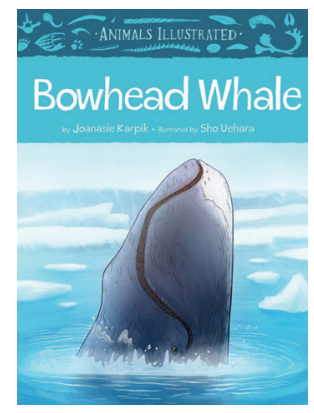

Readers will learn how bowhead whales raise their babies, where they live, what they eat, and other interesting facts. They will also learn traditional uses of the whale by Inuit peoples, such as making tent frames from bowhead whalebones. Joanasie Karpik is a respected elder from Pangnirtung, Nunavut. For ages 4-8.

\section{You Are Never Alone}

Elin Kelsey

and Soyeon Kim

This poetic text uses current science to show how humans survive through our connections to the nature that exists around us. Soyeon Kim's watercolourand-ink diorama-art beautifully extends this fascinating text. For ages 4-8+.

\section{The Not-So Great Outdoors \\ Madeline Kloepper}

The young narrator of this story is unhappy heading into an outdoor vacation and worried that it isn't going to be fun. One step at a time, exciting possibilities reveal themselves and the experience turns out to be great! The mixed-media artwork, finished digitally, is lush and captivating. For ages $5^{-8}$.

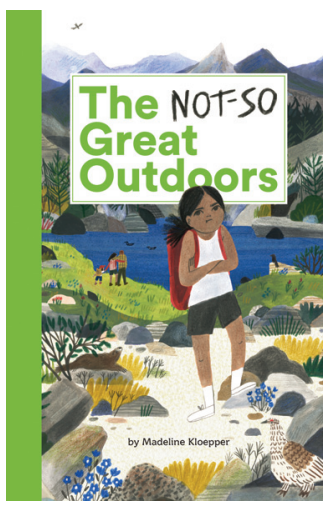

\section{Be a City Nature Detective \\ Peggy Kochanoff}

Through question-and-answer format, this title presents facts about bedbugs, cockroaches, rats, and other animals, as well as birds and plants commonly found in an urban environment. It concludes with a visual quiz, a glossary, and a page of additional resource ideas. The watercolour illustrations offer an engaging glimpse into the often taken-for-granted wonders of city life. For ages 8-11.

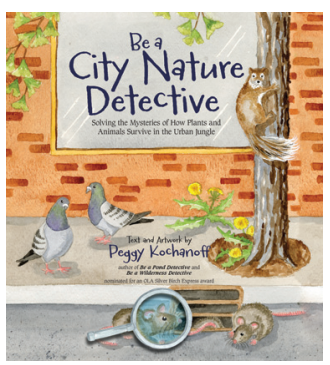


Be a Weather Detective

Peggy Kochanoff

The mysteries of nature are explored here in terms of cycles, seasons and elements. As with Peggy Kochanoff's earlier title, activities, a glossary, and additional resource ideas are included. The watercolour artwork provides an enjoyable window into distinct weather conditions and patterns. For ages 8-11.

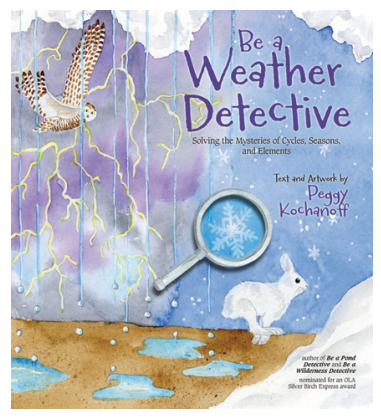

\section{Bat Citizens: Defending the Ninjas of the Night} Rob Laidlaw

This is an informative book about bats, their importance to a wide range of ecosystems, and the young "Bat Citizens" who assist in worldwide bat conservation. Detailed photos as well as a table of contents, lists of additional resources, a glossary, and an index, support learning. At 48 pages, this title is a combination of picture book and juvenile literature

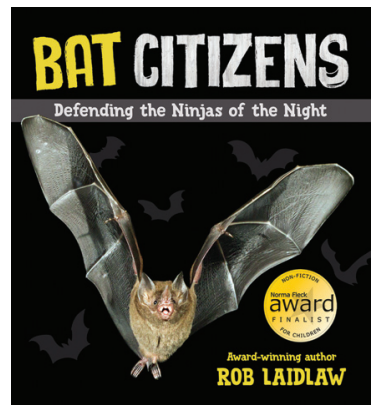
resource. For ages 8-12+.

\section{Me, Toma and the Concrete Garden}

Andrew Larsen

and Anne Villeneuve

Two city children throw dirt balls into an empty lot, not realising they're filled with seeds, and they are surprised and delighted by the resulting flower garden. Anne Villeneuve's ink and watercolour illustrations depict this joyful story well. For ages 6-10.

\section{My Forest is Green}

Darren Lebeuf

and Ashley Barron

This simple story tells all the many ways a young boy can describe a forest in an urban setting. Ashley Barron's stunning artwork here combines cut-paper collage, watercolour, acrylic, and pencil crayon. For ages $3-7$. 


\section{The Biggest Puddle in the World}

Mark Lee

\section{and Nathalie Dion}

Two children explore nature with their grandfather after a long rain. Through its simple story, as well as its illustrations that are a mix of real and digital watercolours, this story celebrates the water cycle. For ages $4-8$.

\section{The Moon Watched It All}

Shelley Leedahl

and Aino Anto

Each night Mirada talks to her only companion, the moon. When a nameless boy takes refuge in her garden, the old woman begins to remember her own children, long gone, and he has thoughts about someone - his mother - from years past. The two of them, with the moon's help, become family. The treatment of the moon here is respectful and unusual. Part fairy tale, part allegory, Shelley Leedahl's engaging text is accompanied by Aino Anto's dreamy watercolour illustrations. For ages $7^{-9+}$.

\section{A Bear's Life \\ Ian McAllister \\ and Nicholas Read}

This title celebrates The Great Bear Rainforest and offers easy-to-read text along with information in Ian McAllister's aweinspiring photographs about the setting and lives of the spirit bear - the white

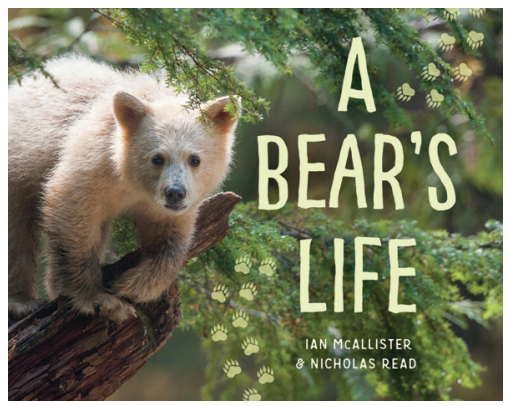
phase of black bears only found in this environment. The book also includes the Indigenous story about their colour it is a reminder of the Ice Age and a promise by Raven that they would be expert fishers. For ages $5^{-8}$. 
The Seal Garden

Ian McAllister

and Nicholas Read

This book focuses on areas in the Great Bear Sea called seal gardens, arrangements of rocks including seals. Ian McCallister's brilliant photographs complement and extend the short, descriptive text. For ages $5^{-8}$.

\section{A Whale's World}

\section{Ian McAllister}

and Nicholas Read

Ian McAllister's stunning photographs, combined with McAllister and Read's informative text, follows a pod of spy-hopping orcas as they explore the ecosystems of the Great Bear Sea. Readers will gain appreciation for the complex coastal food web through this title. For ages 5-8. that provide protection to many animals,
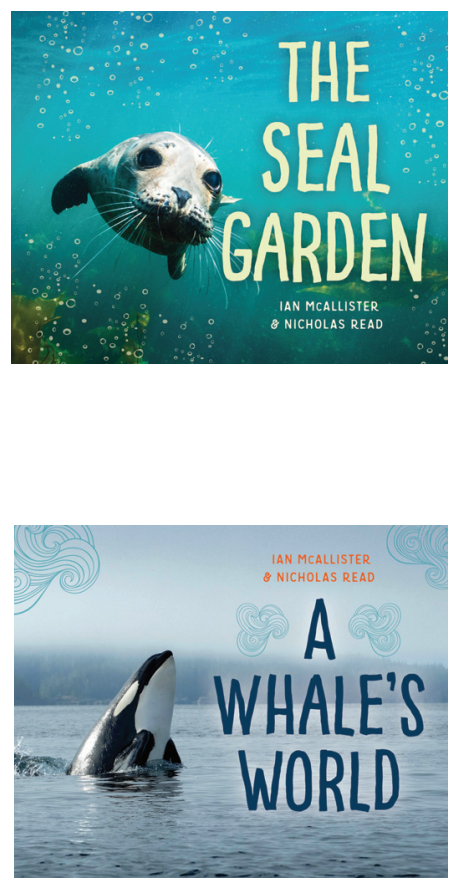

Wolf Island

Ian McAllister

and Nicholas Read

This is a narrative non-fiction account of one of the wolves that lives in The Great Bear Rainforest. Both the text and Ian McAllister's photographs represent this setting as truly a place of wonder. For ages $5^{-8}$.

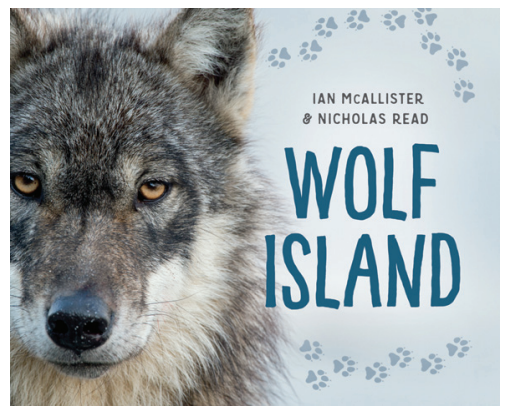




\section{Big Blue Forever \\ Anita Miettunen}

In 1987, a deceased whale washed ashore in Prince Edward Island. It received a careful burial and then years later, when the bones could be helpful to science, it was retrieved for display in Vancouver's biodiversity museum. The book combines information about the whale with facts on the science of moving and preserving its bones as well as short biographies of the team of scientists involved. Informative photographs and suggestions for additional resources complete the package. For ages 9-12+.

\section{My First Book of Canadian Birds \\ Andrea Miller \\ and Angela Doak}

This simple introduction to 14 Canadian birds combines a guessing game pattern with detailed illustrations. Angela Doak's compelling collage images are created with fabric, candy and gum wrappers, and other print sources. For ages $3-8$.

\section{One Wild Christmas}

Nicholas Oldland

Three animal friends plan to celebrate Christmas but when it comes to cutting down the tree, they have a better, more environmentally friendly idea. The digital illustrations are vibrant and rambunctious. This is a further title in Nicholas Oldland's "Life in the Wild" series. For ages 3-7.

\section{Keep Up, Katmai}

Pili Palm-Leis

and Barrett Hedges

Katmai learns to fish for salmon with her brothers and sister. This narrative picture book celebrates the bond between parents and children. Barret Hedges' stunning photographs of grizzlies in their natural surroundings will encourage lots of talk as adults read this story with a younger audience. For ages $3-8$.

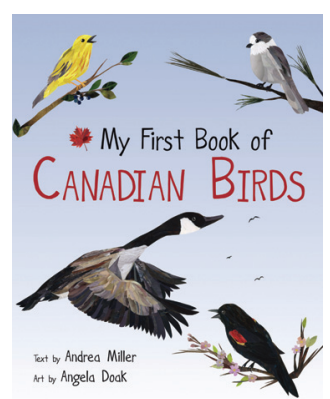


Walrus

Herve Paniag

and Ben Shannon

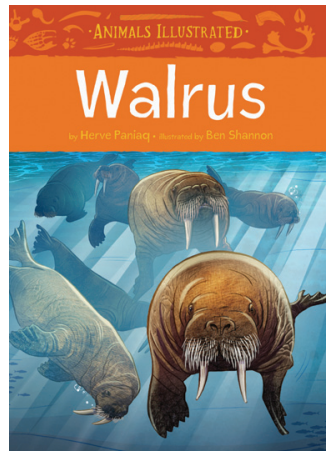

This clear and informative book from the "Animals Illustrated" series takes readers through walrus biology and habitat. Particularly noteworthy is a section on traditional uses, including Inuit hunting tools and meat preparation. Herve Paniaq is an elder from Igloolik, Nunuvut. For ages $4-8$.

Me and You and the Red Canoe

Jean E. Pendziwol

and Phil

Through lyrical free verse, audiences hear via a first-person perspective the experiences of two siblings during a summer morning on the lake. The textured illustrations by Phil are striking, created with acrylic on wood panels, offering a nostalgic landscape for this evocative nature story. For ages $5^{-12+.}$

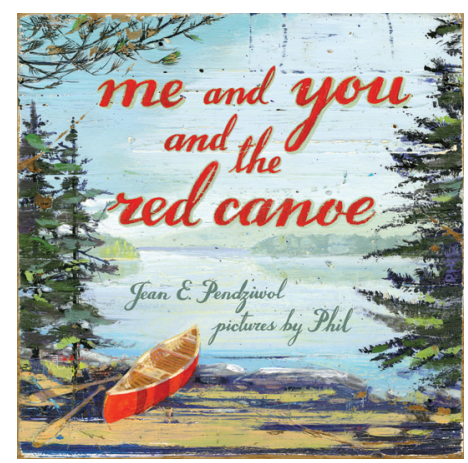

\section{Poetree}

Caroline Pignat

and François Thisdale

This text includes rhyming couplets to introduce each season as well as acrostic poetry. Words and images combine in a sensory celebration of life. François Thisdale's mixed-media illustrations fuse hand-drawn and digital elements for a brilliant impression of seasonal change. For ages $5^{-10+}$. 


\section{Beastly Puzzles: A Brain-Boggling Animal Guessing Game}

Rachel Poliquin

and Byron Eggenschwiler

This interactive text poses questions that help readers think carefully about animal characteristics and then guess a variety of unknown creatures. It conveys appreciation for the complex composition of animals around us and their adaptations, and includes a glossary and additional information about the ways early explorers categorised unfamiliar living things. Byron Eggenschwiler's digitally polished ink illustrations are a monochromatic delight. For ages 7-10+.

\section{Picture the Sky \\ Barbara Reid}

This simple text presents many views of the sky including a lightning show and northern lights along with endpapers that present diverse thumbnails that include a homage to the skies of Vincent Van Gogh and Edvard Munch. Barbara Reid's distinctive images are made with modelling clay shaped and pressed onto illustration board. For ages $3-8$.

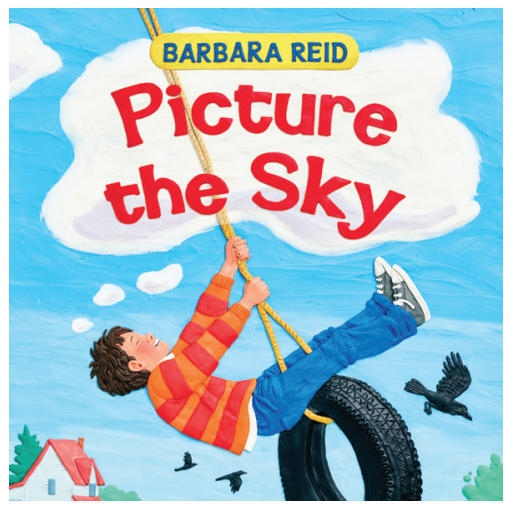

Follow that Bee! A First Book of Bees in the City

Scot Ritchie

Five friends learn about urban beekeeping from an adult mentor in this addition to the "Exploring Our Community" series. This narrative non-fiction title, illustrated with colourful, digitally-rendered images, has a table of contents, instructions for creating a bee bath, and a section of "words to know." For ages 4-8. 


\section{Spur, a Wolf's Story}

Eliza Robertson

and Nora Aoyagi

This story about a young wolf named Spur, and her family, explores what happens when she is injured by a bullet from a helicopter of hunters. It opens the debate about culling wolf populations and advocates for compassion for a vulnerable species. Resources for locating additional information are included. Nora Aoyagi's evocative illustrations were created in acrylic gouache and coloured pencil on watercolour paper. For ages $5^{-9+}$.

\section{Bugs from Head to Tail \\ Stacey Roderick \\ and Kwanchai Moriya}

A guessing game in question-and-answer format encourages young readers to look more closely at bugs. A double-page spread at the end introduces readers to more information about the group of bugs in this book: arthropods. Kwanchai Moriya's vivid artwork was created in Adobe Photoshop and Illustrator, using original photographs and textures. For ages $3-8$.

\section{Hello, Crow!}

Candace Savage

and Chelsea O'Byrne

An observant little girl named Franny makes friends with a crow. The author has included an additional page of information about crows, and the book reminds us of the entertainment we can find outdoors simply by using our senses. For ages $4-8$.

\section{Tree Song}

Tiffany Stone

and Holly Hatam

This book in gentle verse celebrates the life cycle of the oak and reminds us of the importance of conservation. Holly Hatam's illustrations combine simple line drawings, texture, photography, and organic paint. For ages $3-7$.

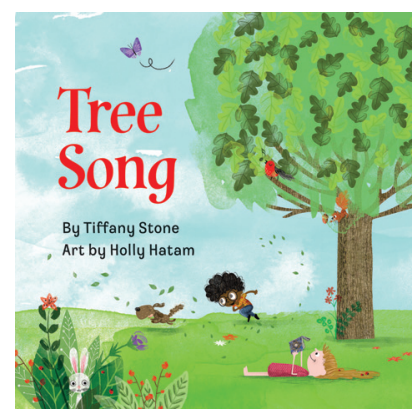




\section{Different? Same!}

Heather Tekavec

and Pippa Curnick

In this creative book the differences and similarities of various animals are examined. While each animal proclaims its special characteristics related to looks, settings or activities, a sentence on each double-page spread tells how a set of seemingly different animals is also the same, a quiet metaphor for human diversity. More information is provided at the end of the book about common animal characteristics and their purpose. Pippa Curnick's playful, textured digital illustrations, created in Adobe Photoshop, are bright and alluring. For ages $2-8$.

\section{The Triumphant Tale of the House Sparrow} Jan Thornhill

This digitally-illustrated account of the house sparrow, including concerns about its current decline, shares its beginnings in the Middle East to its spread alongside agriculture to other countries. The book concludes with the idea that even now, this clever bird might be adapting. Additional pages include a glossary and recommended websites and articles for further information. For ages 9-12+.

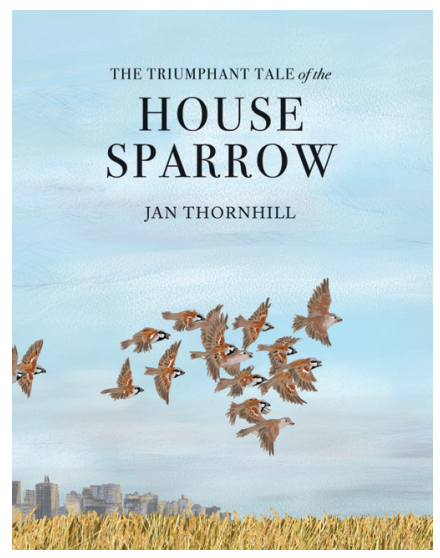

\section{An Owl at Sea}

Susan Vande Griek

and Ian Wallace

This story, told in spare, free verse, is based on a true story about a short-eared owl that landed on an oil rig in the middle of the North Sea. Further information is included about owls at the end of the book along with suggestions for further reading. Ian Wallace's original watercolour illustrations are spectacular, and were created on natural cotton paper that is chlorine and acid-free. For ages $5^{-10+}$. 


\section{Bibliography}

*In the spirit of the recommendations of the Truth and Reconciliation Commission, an asterisk appears beside works created by Indigenous writers or artists.

Assaly, Melissa (illustrated by April Dela Noche Milne) (2019). The Imperfect Garden. Markham, ON: Fitzhenry \& Whiteside.

Barss, Patchen (illustrated by Todd Stewart) (2018). Flow Spin Grow: Looking for Patterns in Nature. Toronto, ON: Owlkids Books.

Burke, Tyler Clark (2019). Where Are You Now? Toronto, ON: Owlkids Books.

Gamblin, Kate Moss (illustrated by Karen Patkau) (2019). Forest: A See to Learn Book. Toronto, ON: Groundwood Books/House of Anansi Press.

Gladstone, James (illustrated by Christy Lundy) (2018). Earthrise: Apollo 8 and the Photo that Changed the World. Toronto, ON: Owlkids Books.

Gladstone, James (illustrated by Karen Reczuch) (2018). Turtle Pond. Toronto, ON: Groundwood Books/House of Anansi Press.

Gladstone, James (illustrated by Katherine Diemert) (2017). When Planet Earth Was New. Toronto, ON: Owlkids Books.

Graham, Georgia (2018). When Wolves Howl. Markham, ON: Red Deer Press.

*Hetxw'ms, Gyetxw (Brett David Huson) (illustrated by Natasha Donovan) (2017). The Sockeye Mother. Winnipeg, MB: Highwater Press.

Hogan, Eric \& Hungerford, Tara (2019). The Case of the Growing Bird Feeder. Richmond Hill, ON: Firefly Books.

Hogan, Eric \& Hugerford, Tara (2019). The Case of the Story Rock. Richmond Hill, ON: Firefly Books.

Hogan, Eric \& Hugerford, Tara (2019). The Case of the Vanishing Caterpillar. Richmond Hill, ON: Firefly Books.

Hogan, Eric \& Hungerford, Tara (2019). The Case of the Wooden Timekeeper. Richmond Hill, ON: Firefly Books.

Hume, S. E. (illustrated by Jessica Bromley Bartram) (2017). Charles. Markham, ON: Fitzhenry \& Whiteside.

Kaner, Etta (illustrated by John Martz) (2018). Do Frogs Drink Hot Chocolate? How Animals Keep Warm. Toronto, ON: Owlkids Books.

Kaner, Etta (illustrated by Marilyn Faucher) (2017). Animals Do, Too! How They Behave Just Like You. Toronto, ON: Kids Can Press.

*Karpik, Joanesie (illustrated by Sho Uehara) (2017). Bowhead Whale. Iqaluit, NU: Inhabit Media.

Kelsey, Elin (illustrated by Soyeon Kim) (2019). You Are Never Alone. Toronto, ON: Owlkids Books. 
Kloepper, Madeline (2019). The Not-So Great Outdoors. Toronto, ON: Tundra Books/ Penguin Random House.

Knowles, Laura (illustrated by James Boast) (2017). Once Upon a Jungle. Richmond Hill, ON: Firefly Books.

Kochanoff, Peggy (2018). Be a City Nature Detective. Halifax, NS: Nimbus Publishing.

Kochanoff, Peggy (2019). Be a Weather Detective. Halifax, NS: Nimbus Publishing.

Laidlaw, Rob (2018). Bat Citizens:Defending the Ninjas of the Night. Toronto, ON: Pajama Press.

Larsen, Andres (illustrated by Anne Villeneuve) (2019). Me, Toma and the Concrete Garden. Toronto, ON: Kids Can Press.

Lebeuf, Darren (illustrated by Ashley Barron) (2019). My Forest is Green. Toronto, ON: Kids Can Press.

Lee, Mark (illustrated by Nathalie Dion) (2019). The Biggest Puddle in the World. Toronto, ON: Groundwood/House of Anansi Press.

Leedahl, Shelley (illustrated by Aino Anto) (2019). The Moon Watched It All. Markham, ON: Red Deer Press.

McAllister, Ian \& Read, Nicholas (2017). A Bear's Life. Victoria, BC: Orca Book Publishers.

McAllister, Ian \& Read, Nicholas (2017). Wolf Island. Victoria, BC: Orca Book Publishers.

McAllister, Ian \& Read, Nicholas (2018). A Whale's World. Victoria, BC: Orca Book Publishers.

McAllister, Ian \& Read, Nicholas (2018). The Seal Garden. Victoria, BC: Orca Book Publishers.

Miettunen, Anita (2017). Big Blue Forever. Markham, ON: Red Deer Press.

Miller, Andrea (illustrated by Angela Doak) (2018). My First Book of Canadian Birds. Halifax, NS: Nimbus Publishing.

Oldland, Nicholas (2019). One Wild Christmas. Toronto, ON: Kids Can Press.

Palm-Leis, Pili (illustrated by Barrett Hedges) (2019). Keep Up, Katmai. Markham, ON: North Winds Press/Scholastic Canada.

*Paniaq, Herve (illustrated by Ben Shannon) (2017). Walrus. Iqualuit, NU: Inhabit Media.

Pendziwol, Jean E. (illustrated by Phil) (2017). Me and You and the Red Canoe. Toronto, ON: Groundwood Books/House of Anansi Press.

Pignat, Caroline (illustrated by François Thisdale) (2018). Poetree. Markham, ON: Red Deer Press.

Poliquin, Rachel (illustrated by Byron Eggenschwiler) (2019). Beastly Puzzles: A BrainBoggling Animal Guessing Game. Toronto, ON: Kids Can Press.

Reid, Barbara (2017). Picture the Sky. Toronto, ON: North Winds Press/Scholastic Canada. 
Ritchie, Scot (2019). Follow that Bee! A First Book of Bees in the City. Toronto, ON: Kids Can Press.

Robertson, Eliza (illustrated by Nora Aoyagi) (2019). Spur, a Wolf's Story. Vancouver, BC: Greystone Books.

Roderick, Stacey (illustrated by Kwanchai Moriya) (2017). Bugs From Head to Tail. Toronto, ON: Kids Can Press.

Savage, Candace (illustrated by Chelsea O’Byrne) (2019). Hello, Crow! Vancouver, BC: Greystone Books.

Stone, Tiffany (illustrated by Holly Hatam) (2018). Tree Song. Toronto, ON: Annick Press.

Tekavec, Heather (illustrated by Pippa Curnick) (2017). Different? Same! Toronto, ON: Kids Can Press.

Thornhill, Jan (2018). The Triumphant Tale of the House Sparrow. Toronto, ON: Groundwood Books/House of Anansi Press.

Vande Griek, Susan (illustrated by Ian Wallace) (2019). An Owl at Sea. Toronto, ON: Groundwood Books/House of Anansi Press. 